\title{
Developing an Innovative Pandemic Treaty to Advance Global Health Security
}

Lawrence O. Gostin

Georgetown University - Law Center - O'Neill Institute for National and Global Health Law, gostin@law.georgetown.edu

Benjamin Mason Meier

University of North Carolina at Chapel Hill, bmeier@unc.edu

Barbara Stocking

Murray Edwards College, University of Cambridge

This paper can be downloaded free of charge from:

https://scholarship.law.georgetown.edu/facpub/2424

https://ssrn.com/abstract=3887059

The Journal of Law, Medicine \& Ethics, Vol. 49, 2021, Pp. 503-508.

This open-access article is brought to you by the Georgetown Law Library. Posted with permission of the author. Follow this and additional works at: https://scholarship.law.georgetown.edu/facpub

Part of the Health Law and Policy Commons 


\title{
Developing an Innovative Pandemic Treaty to Advance Global Health Security
}

\author{
Lawrence O. Gostin, Benjamin Mason Meier \& Barbara Stocking
}

\begin{abstract}
Recognizing marked limitations of global health law in the COVID-19 pandemic, a rising number of states in the World Health Assembly have proposed the development of a new pandemic treaty. This prospective treaty has the potential to clarify state obligations for pandemic preparedness and response and strengthen World Health Organization authorities to promote global health security. This column examines the necessary scope and content of a pandemic treaty, analyzing the policymaking processes and substantive authorities necessary to meet this historic moment.
\end{abstract}

Keywords: Global Health Law, Pandemic Treaty, World Health Organization, COVID-19

The World Health Assembly will be holding an unprecedented second meeting this year, with only a single item on the agenda for this November 2021 meeting - the development of a new pandemic treaty. This pandemic treaty provides a path to develop international legal obligations through the World Health Organization (WHO). Yet despite strong international political support for such a treaty, there has been little examination of its potential scope, substance, and legal process.

This column explores the legal content of a prospective pandemic treaty, offering guidance on its key elements and potential processes. Recognizing stark failures in global governance during the COVID-19 pandemic, this new treaty is intended to clarify state obligations to prevent, detect, and respond to pandemic threats and to strengthen WHO powers. The treaty, therefore, must develop innovative norms, governance, and compliance mechanisms needed to prepare for novel outbreaks with pandemic potential.

Examining the development of global health law reforms, this column opens by reviewing the evolution of international legal agreements governing global health security. However, the COVID-19 pandemic has exposed continuing limitations of international law and weaknesses of WHO authorities. These limitations provide the impetus for a new international legal agreement to strengthen pandemic preparedness and response. This column analyzes potential treaty structures and substantive authorities needed to face future pandemic threats. We end by reflecting on diplomatic challenges that states must confront in bringing the world together to develop a bold new treaty to advance global health security.

\section{WHO Legal Authorities to Develop Global Health Law}

States have provided WHO with expansive legal authorities to develop global health law. Pursuant to these powers, the World Health Assembly has codified evolving authorities to coordinate international action to prevent, detect, and respond to pandemic threats. 


\section{WHO Constitution as a Mandate for Global Health Lawmaking}

Under the 1946 WHO Constitution, states declared the "highest attainable standard of health" to be a fundamental human right, providing WHO with authority to develop international law on any public health matter through the adoption of:

- conventions (article 19) - treaties and agreements that set standards to promote public health,

- regulations (article 21) - legally-binding standards that designate specific actions that must be taken by member states, and

- recommendations (article 23) - non-binding guidelines that provide member states with guidance on how to promote public health. ${ }^{1}$

Although WHO was created as a normative agency, with a constitutional mandate to develop global health law, the organization has long been reluctant to exercise its legal authority under article 19 to develop conventions, looking instead to article 21 in advancing the International Health Regulations (IHR). ${ }^{2}$

\section{International Law to Prevent, Detect, and Respond to Pandemics}

The IHR stand as the leading legal agreement to respond to the globalized threat of infectious diseases. Originating out of the international sanitary agreements that predated WHO, the World Health Assembly has revised the IHR several times to respond to changing health threats across national borders. ${ }^{3}$ The current IHR, revised comprehensively in 2005 following the SARS-1 epidemic, has broad participation from WHO member states, with 196 states parties adopting the regulations to guide efforts to prevent, detect, and respond to a disease outbreak. In balancing measures to facilitate global health security while maintaining international travel, trade and human rights, the IHR empower WHO and member states in detecting and responding to public health emergencies of international concern. ${ }^{4}$

Beyond the IHR's binding norms, states have negotiated non-binding "soft law" frameworks to advance health security. The Pandemic Influenza Preparedness (PIP) Framework, while limited to pandemic influenza strains, brings together WHO, member states, and non-state actors (e.g., pharmaceutical companies and academic laboratories) to help ensure international sharing of novel influenza pathogens, facilitating equitable distribution of the benefits of influenza research in developing vaccines and therapeutics. ${ }^{5}$ Outside WHO, states and international organizations have come together to establish the Global Health Security Agenda (GHSA) to enhance country capacities to prevent, detect, and respond to infectious diseases, emphasizing global health security as a national priority and targeting multisectoral gaps in national policy. ${ }^{6}$

\section{Limitations of Global Health Law in the COVID-19 Response}

The COVID-19 pandemic has revealed deep flaws in pandemic preparedness and response, as the IHR have faced limitations in shaping national responses and political controversies have weakened WHO governance and institutional capacities. 


\section{IHR Limitations}

The international response to the unfolding COVID-19 pandemic has exposed severe limitations in IHR obligations (and state compliance) to shape an effective coordinated response to global public health emergencies. Despite major IHR reforms in 2005, the national and global response to COVID-19 has seen:

Failures to notify WHO promptly of novel outbreaks. The IHR require states parties to report to WHO "timely, accurate and sufficiently detailed public health information." China appeared to violate this norm by failing to promptly report a novel coronavirus circulating in Wuhan. WHO discovered the outbreak from "unofficial" sources, and even then, China downplayed the extent of community transmission. Since that time, China has not fully cooperated with WHO in impartially investigating the origins of SARS-CoV-2. The inability of WHO to investigate events independently created delays in detection of, and response to, a novel coronavirus outbreak.

Delays in declaring a Public Health Emergency of International Concern (PHEIC). This inadequate reporting - compounded by a split in expert opinion, misapplication of the legal definition of a PHEIC, and WHO's diplomatic hesitation-prevented a timely WHO PHEIC declaration, by which point a pandemic was already well underway. While the WHO Director General did promptly declare a PHEIC on January 30, 2020, there were confused signals five weeks later when the Director-General declared a "pandemic," as WHO has no formal legal power to declare pandemics under the IHR.

Non-compliance with WHO recommendations on outbreak response. It is important to effectively manage an outbreak response at the global level as it spreads internationally. Yet, WHO was unable to influence state measures to contain the pandemic through evidence-based interventions. WHO's public health guidance and temporary recommendations were repeatedly ignored by member states, with WHO lacking compliance mechanisms to monitor, investigate, and remediate harmful actions.

State health measures disproportionate to public health risks. States rapidly imposed sweeping restrictions on international traffic, economic activity, and individual rights, with many state actions taken without adequate public health justification. Virtually every state would turn to complete, or substantial, bans on entry of international travelers, and while some countries imposed travel restrictions early as a valid public health measure, others acted arbitrarily or with discriminatory intent. With rising human rights violations and democratic backsliding, some heads of state used the crisis as a justification for expanding their powers through autocratic policies and practices.

Lack of global solidarity and equitable allocation of medical resources. Neglecting IHR obligations of international assistance and cooperation, states largely reverted to isolationist policies, geopolitical competition, and global neglect, which served to undermine a coordinated response, threaten WHO support, and lead to vaccine inequities. Even today, as many highincome nations have achieved high vaccination coverage and are returning to some normalcy, 
most low- and middle-income states face an extreme scarcity of vaccine doses, medical treatments, oxygen supplies, and personal protective equipment. ${ }^{7}$

COVID-19 has highlighted the lack of clarity of state obligations, the failure of political will to follow public health guidance, and the absence of meaningful accountability for IHR violations, weakening WHO governance in the pandemic.

\section{WHO Weaknesses}

Global health law further shapes WHO's legal and normative authority to lead the international response to novel outbreaks. The WHO's leadership has been tested by the pandemic as never before. Although global health law depends on strong governance, WHO has been unable to rally global solidarity throughout the pandemic where it lacks the legal authority and financial resources to effectively coordinate the public health response. ${ }^{8}$ Without the ability to independently verify state reports, inspect conditions on the ground, or to hold states to account, WHO has at times floundered, drawing on "soft" power to guide the global health response. ${ }^{9}$ These weaknesses in WHO governance call into question the continuing effectiveness of global health law and raise an imperative to develop a bold new pandemic treaty. It also makes it important for the international community to come together in support of WHO, giving it political support, ample funding, and strong legal powers.

\section{Proposals for a Pandemic Treaty}

Overcoming limitations in the COVID-19 response, many proponents of a pandemic treaty have looked to WHO's rarely used constitutional authority to develop a binding international convention, providing a legal foundation for proposals to develop a new treaty through the World Health Assembly.

\section{Early Proposals}

Early proposals for a pandemic treaty arose out of academic analysis. Recognizing gaps in the scope of the IHR - especially relating to the production of and access to necessary equipment, medicines, and vaccines - scholars began to argue that a new treaty would strengthen WHO authority and generate financial resources for a pandemic response. ${ }^{10}$ Given that the IHR focus on outbreak detection rather than disease prevention, scholars pushed for a pandemic treaty to have a "deep prevention" core mandate, providing a vital "one health" perspective (especially around zoonotic disease) and a focus on upstream determinants of disease outbreaks. ${ }^{11}$ Beyond these substantive provisions, scholars and advocates recognized that key cross-cutting legal principles must serve as a foundation of the treaty, advancing principles of equity, human rights, and accountability. ${ }^{12}$ These early contributions would influence formal evaluations of the pandemic response and recommendations for fundamental reforms.

\section{IPPPR Reports}

WHO's Director-General appointed the Independent Panel on Pandemic Preparedness and Response (IPPPR) to examine why COVID-19 became a global health crisis and to ensure that 
future infectious diseases outbreaks do not lead to another catastrophic pandemic. In preparing its report, the IPPPR commissioned a background paper on international law, with this paper concluding that "a Framework Convention - Protocol approach" to a pandemic treaty could facilitate governance reforms "in coherence with the broader international legal system, including under, or separate to, the auspices of the World Health Organization and with, or without, reforms to existing global health law, such as the International Health Regulations (2005)." ${ }^{13}$ Drawing from WHO's past experience in developing an article 19 convention through the Framework Convention on Tobacco Control (FCTC), the final IPPPR report recommended that states:

Adopt a Pandemic Framework Convention within the next 6 months, using the powers under Article 19 of the WHO Constitution, and complementary to the IHR, to be facilitated by WHO and with the clear involvement of the highest levels of government, scientific experts and civil society. ${ }^{14}$

The IPPPR also recommended a broader global pandemic architecture, including a Global Health Threats Council endorsed by the United Nations General Assembly. Supported by the G20 High Level Independent Panel on Financing the Global Commons for Pandemic Preparedness and Response, this Council would ensure high level political leadership and attention to pandemic prevention, preparedness, and response, with authority, financing, and accountability mechanisms to overcome gaps in national and global capacities. ${ }^{15}$

\section{World Health Assembly Debates}

Delegates during the May 2021 World Health Assembly debated the development of a pandemic treaty to strengthen national, regional, and global capacities and guide a coordinated international response to future pandemic threats. Leading up to the World Health Assembly, twenty-five heads of government and international agencies (including WHO Director-General Tedros Adhanom Ghebreyesus) joined in an extraordinary call to support a new treaty for pandemic preparedness and response, signaling high-level political action to protect the world from future health crises. ${ }^{16}$ Director-General Tedros remained steadfast in his support for this pandemic treaty, arguing that such a treaty could promote increased sharing, trust, and accountability, establishing the basis upon which to build other global health security mechanisms. ${ }^{17}$

World Health Assembly debates centered around the exact nature of international law that should be employed — whether a framework convention, regulations, or WHO recommendations — and whether this legal development should be pioneered under the auspices of WHO. ${ }^{18}$ Instead of convening an intergovernmental working group to begin negotiations on the text of a pandemic treaty, the Assembly resolved to hold a "special session" in November to focus on this singular issue. Some states had argued that further discussions about developing the treaty should be delayed until the pandemic is further contained, but others called for a special session to develop the treaty immediately, suggesting that states start negotiations quickly to be prepare for a November special session of the World Health Assembly.

\section{Developing a Pandemic Treaty}


These processes and proposals will be crucial as states prepare for World Health Assembly debates in November, which will consider "the benefits of developing a WHO convention, agreement, or other international instrument on pandemic preparedness and response with a view towards the establishment of an intergovernmental process to draft and negotiate such convention, agreement, or other international instrument on pandemic preparedness and response." 19

\section{Policymaking Processes}

Wide ranging diplomatic efforts will take place through WHO, the United Nations, and other international forums that will shape the processes for developing a pandemic treaty. In determining the agenda of the Special Session, the WHO Executive Board will be meeting to decide the intergovernmental processes to draft and negotiate an international instrument. These initial debates will examine the exact legal nature of the proposed instrument and how this new legal authority will relate to the IHR.$^{20}$ Leading up to the special session in November, a WHO Working Group on Strengthening WHO Preparedness and Response to Health Emergencies will be meeting to assess the possibility of a WHO convention or other global agreement. This Working Group will submit a report to the World Health Assembly, examining the benefits of a WHO treaty and supporting states as they discuss and negotiate the nature of this guiding international instrument. The O'Neill Institute for National and Global Health Law at Georgetown University (a WHO Collaborating Center) is partnering with the Foundation of the National Institutes of Health to support WHO and member states in the pandemic treaty process.

\section{Substantive Authorities}

In identifying the specific strategies for preventing, detecting, and responding to future pandemics, this prospective global health convention provides a unique opportunity to articulate key state obligations, with strong compliance and accountability mechanisms for:

One Health. Prioritizing prevention through land management, deforestation, and the effective regulation of wild animal markets and intense human-animal interchange-under a comprehensive "one health" approach across sectors - the new treaty could reduce the likelihood of naturally-occurring zoonotic spillovers and other novel threats. ${ }^{21}$

Biosecurity and Biosafety. The treaty should address biosecurity and biosafety to ensure that laboratory conditions do not lead to disease outbreaks, creating mechanisms to reduce the possibility of inadvertent or intentional release of dangerous pathogens through the regulation of gain-of-function research and laboratory safety protocols.

International Monitoring. In promoting outbreak prevention, detection, and response, strengthened global institutions must overcome obstacles of national sovereignty in order to monitor disease threats. International institutions like WHO must have authority to verify state reports, publish crucial outbreak data without state confirmation, investigate novel pathogens independently, and institute remedial actions. ${ }^{22}$ 
Advancing Research and Data Transparency. Global governance also must seek to advance biomedical research to develop therapeutic countermeasures (e.g., diagnostics, vaccines, and treatments). This requires sharing of pathogen and genomic sequencing data, also with norms of full transparency and scientific cooperation.

This new pandemic treaty must seek not only to construct strong national authorities that reflect good public health practice, but moreover must establish a system of good governance to advance the right to health and human rights principles of equity, transparency and accountability in the pandemic response:

Good Governance. It is crucial that the new treaty stresses an evidence-based public health response while proscribing and sanctioning iniquitous government actions, including "authoritarian power grabs", continuing monopolies in medical innovations, failure to resource health systems, heightened levels of pandemic-related hate crimes and violence, and an institutional neglect of low-income and marginalized communities. ${ }^{23}$

Right to Health. Following from the WHO Constitution and core international human rights treaties, the pandemic treaty must be grounded in the human right to health, framing efforts to maintain core public health capacities; ensure the availability, accessibility, and quality of health services; provide access to basic needs during lockdowns; and align global health law with human rights law in framing derogations of human rights to protect public health. ${ }^{24}$

Human Rights Principles. Looking more broadly to human rights as a foundation of the pandemic treaty would provide a cross-cutting lens through which to assess rights-based public health practices, including equity and non-discrimination in the pandemic response, participation from affected communities, transparency in government decision-making, and accountability for health outcomes. ${ }^{25}$

In carrying out the aspirations laid out in developing and implementing a pandemic treaty, it will be crucial to strengthen global health governance through WHO and other global actors. While Dr. Tedros has become the world's moral conscience in the pandemic response, WHO has lacked the power, funding, and political backing to become the bold leader necessary to meet this historic moment. This unprecedented public health crisis offers a unique opportunity to reform WHO authorities and establish a broader global pandemic prevention and response architecture to coordinate pandemic preparedness on a global scale, partner with other international organizations in a pandemic response, and ensure international assistance and cooperation through global health governance:

WHO Authority. In leading the response to pandemic threats, WHO must have a strengthened mandate for building national health system capacities, coordinating international collaboration, and influencing state behavior, with states conferring power to WHO to coordinate international action against pandemic-level threats and establishing mechanisms to facilitate accountability from non-compliant states. ${ }^{26}$

Institutional Partnerships. It will be crucial for WHO to work with other institutions of global health governance (governments, the private sector, civil society, and other international 
organizations) to support the global response, ensuring fair intellectual property systems, equitable virus sample (and genomic sequencing) sharing, and coordinated research and development systems; and sustaining partnerships developed in the current pandemic to openly share intellectual property, technology, and data for countering diseases. ${ }^{27}$

International Assistance and Cooperation. As a foundation for responding to pandemic threats, it is imperative that the pandemic treaty recognize the ways in which global inequalities in access to vaccines, medicines, and diagnostics have prolonged the pandemic, providing WHO and the wider global pandemic prevention architecture with the authority to work across states to facilitate the equitable distribution of medical resources and establish an International Pandemic Financing Facility to support rapid financing in a pandemic response. ${ }^{28}$ This pandemic has revealed deep health inequities that must be rectified, including through new institutions to speed scientific discoveries and make them available globally.

\section{Global Health Security in the Balance}

These initiatives will be crucial to developing a pandemic treaty that establishes a legitimate governing authority that can overcome many of the limitations of the COVID-19 response. WHO Director-General Tedros has boldly stated that "the world cannot afford to wait until the pandemic is over to start planning for the next one." ${ }^{29}$ If there is one overarching lesson from the COVID-19 pandemic, it is that the world is safer when we work together than when we devolve into fierce nationalism and isolated responses. An innovative pandemic treaty could become a transformative model of global solidarity in the face of common threats, but it will require states to overcome nationalist forces to meet this global moment, with leaders embracing diplomacy across nations to prepare for new challenges.

\section{Disclaimers:}

Dame Barbara Stocking is chair and Lawrence O. Gostin is a member of the independent Panel for a Global Health Convention (GPHC). Prof. Gostin is also Director of the WHO Collaborating Center on National and Global Health Law. This column does not necessarily represent the views of either the GPHC or WHO.

\section{Acknowledgements:}

The authors are grateful to Meredith Dockery, Nicholas Batman, Moonwon Seo, and Sonam Shah for their thoughtful research assistance in developing this column.

\footnotetext{
${ }^{1}$ L.O. Gostin and B.M. Meier, "Introducing Global Health Law” Journal of Law, Medicine \& Ethics, 47 (2019): 788-793.

2 B.M. Meier et al. "The World Health Organization in Global Health Law" Journal for Law, Medicine, and Ethics 48 (2020) 796-799.

${ }^{3}$ L.O. Gostin, Global Health Law, Harvard University Press, 2014.

4 D.P. Fidler and L.O. Gostin, "The New International Health Regulations: An Historic Development for International Law and Public Health" Journal for Law, Medicine, and Ethics, 34 (2006) 85-94.

${ }^{5}$ Michelle Rourke, Mark Eccleston-Turner, Alexandra Phelan, Lawrence Gostin, Policy Opportunities to Enhance Sharing for Pandemic Research, 368 (6492) SCIENCE 716-718 (2020).

${ }^{6}$ R. Katz et al., "Global Health Security Agenda and the International Health Regulations: Moving Forward" Biosecurity and Bioterrorism: Biodefense Strategy, Practice, and Science, 12 (2014) 231-238.
} 
${ }^{7}$ L.O. Gostin, R. Habibi and B.M. Meier, "Has Global Health Law Risen to Meet the COVID-19 Challenge? Revisiting the International Health Regulations to Prepare for Future Threats" Journal for Law, Medicine, and Ethics 48 (2020) 376-381.

${ }^{8}$ A.L. Taylor, et al., "Solidarity in the Wake of COVID-19: Reimagining the International Health Regulations" The Lancet 396 (2020) 82-83.

${ }^{9}$ S. Sekalala and H. Masud, "Soft Law Possibilities in Global Health Law" Journal for Law, Medicine, and Ethics 49 (2021) 152-155.

${ }^{10}$ H. Nikogosian and I. Kickbusch, "The Case for an International Pandemic Treaty" 372 (2021) BMJ.

${ }^{11}$ J. Vinuales, S. Moon, G. Le Moli and G.-L. Burci, "A global pandemic treaty should aim for deep prevention." The Lancet, 397 (2021) 1791-1792.

${ }^{12}$ S. Davis et al., "An International Pandemic Treaty Must Centre on Human Rights”, May 10, 2021, available at <https://blogs.bmj.com/bmj/2021/05/10/an-international-pandemic-treaty-must-centre-on-human-rights/ > (last visited June 25, 2021).

${ }^{13}$ A. Phelan and P. Pillai, "International Health Law in Perspective." May 2021, available at https://theindependentpanel.org/wp-content/uploads/2021/05/Background-paper-16-International-treaties.pdf (last visited June 24, 2021).

${ }^{14}$ The Independent Panel for Pandemic Preparedness \& Response, COVID-19: Make it the Last Pandemic (Geneva: World Health Organization, 2021).

${ }^{15}$ High Level Independent Panel urges the G20 to launch a 'global deal' to prevent catastrophic costs of future pandemics, available at https://www.g20.org/high-level-independent-panel-urges-the-g20-to-launch-a-global-dealto-prevent-catastrophic-costs-of-future-pandemics.html.

${ }^{16}$ World Health Organization, Global leaders unite in urgent call for international pandemic treaty, available at https://www.who.int/news/item/30-03-2021-global-leaders-unite-in-urgent-call-for-international-pandemic-treaty.

${ }^{17}$ T. Adhanom Ghebreyesus, "Director-General's opening remarks at the World Health Assembly - 24 May 2021" opening speech of the World Health Assembly, Geneva, Switzerland, May 24, 2021.

18 J.L. Ravelo, "Draft decision on pandemic treaty expected to be adopted today at WHA," DEVEX, May 26, 2021, available at https://www.devex.com/news/draft-decision-on-pandemictreaty-expected-to-be-adopted-today-at-wha-99994 (last visited on June 25, 2021).

${ }^{19}$ World Health Organization, "Special session of the World Health Assembly to consider developing a WHO convention, agreement or other international instrument on pandemic preparedness and response," May 25, 2021, available at <https://apps.who.int/gb/ebwha/pdf_files/WHA74/A74_ACONF7-en.pdf> (last visited June 25, 2021).

${ }^{20}$ P. Patnaik, "Pandemic Treaty Opponents have Bought Time Till a Special Session of WHA in Nov, Supporters Manage to Keep Pressure On," Geneva Health Files, May 25, 2021, available at https://genevahealthfiles.com/2021/05/25/pandemic-treaty-opponents-have-bought-time-till-aspecial-session-of-wha-in-nov-supporters-manage-to-keep-pressure-on/ (last visited on June 25, 2021).

${ }^{21}$ J.H. Duff, et al., "a global public health convention for the $21^{\text {st }}$ century", Lancet Public Health, May 5, 2021, available at < https://doi.org/10.1016/S2468-2667(21)00070-0> (last visited June 25, 2021).

${ }^{22}$ L.O. Gostin,, S. Wetter and E. Friedman, "This Investigation Lays Out What the World Needs to Fight the Next Pandemic." May 20, 2021, available at $<$ https://www.forbes.com/sites/coronavirusfrontlines/2021/05/20/thisinvestigation-lays-out-what-the-world-needs-to-fight-the-next-pandemic/?sh=5720207c43d4. $>$ (last visited June 24, 2021).

${ }^{23}$ S. Fukuda-Parr, P. Buss, and A.E. Yamin, "Pandemic treaty needs to start with rethinking the paradigm of global health security," BMJ Global Health, 6 (2021).

${ }^{24}$ J. Bueno de Mesquita, A. Kapilashrami, and B.M. Meier, "Strengthening Human Rights in Global Health Law: Lessons from the COVID-19 Response," Journal of Law, Medicine \& Ethics 49 (2021): 328-331. 
${ }^{25}$ K. Knight, “An International Pandemic Treaty Should Center on Human Rights”, Human Rights Watch, May 10, 2021, available at https://www.hrw.org/news/2021/05/10/internationalpandemic-treaty-should-center-human-rights\# (last visited June 25, 2021).

${ }^{26}$ L.O. Gostin, "9 Steps to End COVID-19 and Prevent the Next Pandemic: Essential Outcomes From the World Health Assembly", JAMA Forum, 2 (2021) 6.

${ }^{27}$ L.O. Gostin, S. Abdool Karim, B.M. Meier, "Facilitating Access to a COVID-19 Vaccine through Global Health Law", Journal of Law, Medicine \& Ethics, 48 (2020): 622-626.

${ }^{28}$ M.M Kavanagh, L.O. Gostin, M. Sunder, "Sharing Technology and Vaccine Doses to Address Global Vaccine Inequity and End the COVID-19 Pandemic." JAMA. Published online July 01, 2021. doi:10.1001/jama.2021.10823. ${ }^{29}$ Tedros (2021). WHO Director-General's remarks at the press conference with President of the European Council to discuss the proposal for an international pandemic treaty. https://www.who.int/director-

general/speeches/detail/who-director-general-s-remarks-at-the-press-conference-with-president-of-the-europeancouncil-to-discuss-the-proposal-for-an-international-pandemic-treaty 